\title{
Elektroniczne papierosy a jama ustna
}

\author{
Electronic cigarettes and the oral cavity \\ Katedra i Zakład Periodontologii i Chorób Błony Śluzowej Jamy Ustnej, Uniwersytet Medyczny w Gdańsku
}

DOI: http://dx.doi.org/10.20883/df.2017.25

\begin{abstract}
Streszczenie
Papierosy elektroniczne, stanowiące alternatywę dla tradycyjnego palenia, stają cię coraz bardziej popularne na całym świecie. Początkowo zostały przedstawione jako zdrowsze od tradycyjnych, ale po przeprowadzeniu wielu badań naukowych zaczynają wzbudzać dużo kontrowersji. Zaobserwowano, że w wyniku ekspozycji na aerozol e-papierosów dochodzi do obumierania keratynocytów jamy ustnej oraz zwiększenia wydzielania cytokin prozapalnych przez fibroblasty tkanek przyzębia. Zaobserwowane działanie cytotoksyczne nie było zależne od obecności nikotyny w roztworze. Udowodniono również, że składniki zawarte w aerozolu działają karcynogennie poprzez uszkadzanie struktury DNA, co stanowi podstawę do prowadzenia bardziej szczegółowych badań naukowych uwzględniających długoterminowe skutki palenia e-papierosów.
\end{abstract}

Słowa kluczowe: elektroniczne papierosy, cytotoksyczność, jama ustna.

\begin{abstract}
Electronic cigarettes, considered an alternative to traditional smoking, are becoming increasingly popular around the world. At first they were presented as healthier than traditional cigarettes, but after a lot of scientific research they have become the subject of much controversy. As a result of e-cigarette aerosol exposure, the death of oral keratinocytes and the secretion of proinflammatory cytokines by periodontal fibroblasts have been observed. Those cytotoxic effects were not dependent on the presence of nicotine in the solution of e-liquids. It was also observed that DNA structure damage contributes to the carcinogenic effects of aerosol components, which is the reason for further scientific research in order to determine the long-term effects of e-cigarette usage.
\end{abstract}

Keywords: electronic cigarettes, cytotoxicity, oral cavity.

\section{Wstęp}

Papierosy elektroniczne, odkąd pojawiły się na rynku w 2004 roku, zdobywają coraz większą popularność na całym świecie, również w Polsce [1]. Ze względu na różnorodność smaków i zawartości nikotyny oraz możliwość użytkowania w wielu miejscach publicznych są atrakcyjne dla palaczy, niezależnie od przynależności do określonej grupy społecznej i wiekowej [1-4]. Początkowo przedstawione jako „zdrowsza” alternatywa palenia, obecnie zaczynają budzić kontrowersje, stając się przedmiotem wielu badań naukowych [5]. Skutki palenia papierosów elektronicznych, zwłaszcza długoterminowe, nie zostały dotychczas szczegółowo zbadane [1, 6-8]. Do poznanych niekorzystnych efektów palenia e-papierosów należy suchość w jamie ustnej i gardle, kaszel, zwiększenie oporu oddechowego oraz przyspieszenie akcji serca [1, 9-14]. Obserwuje się również zaburzenia w obrębie jamy ustnej, która jako pierwsza ma kontakt z substancjami zawartymi w aerozolu [12]. Jak wskazują niektórzy badacze, cytotoksyczne działanie e-papierosów na keratynocyty nabłonka jamy ustnej i komórki fibroblastów może powodo- wać choroby przyzębia, jak również prowadzić do rozwoju nowotworów [9, 12].

\section{E-papierosy i ich skład}

Niekwestionowaną zaletą elektronicznych papierosów jest wyeliminowanie szkodliwych oraz karcynogennych substancji zawartych w dymie tytoniowym, takich jak tlenek węgla, wielopierścieniowe węglowodory aromatyczne, fenol, substancje smoliste i wiele innych [15]. Podczas palenia e-papierosów palacz wdycha aerozol powstały z roztworu inhalacyjnego po jego podgrzaniu do temperatury $40-65^{\circ} \mathrm{C}$, która jest wystarczająco wysoka, aby osiągnął stan lotny [16, 17]. Roztwór ten $\mathrm{w}$ większości składa się z glikolu propylenowego, który powoduje powstanie efektu wizualnego podobnego do dymu papierosowego. Badania Bertholon i wsp. wskazały, że nie jest to substancja toksyczna podczas inhalacji i ulega szybkiemu zmetabolizmowaniu (jego okres półtrwania we krwi wynosi 2 godziny) [1]. Niektóre firmy jako główny składnik wykorzystują glicerol albo dodają jego niewielką ilość w celu modyfikacji aerozolu, 
ale wymaga on podgrzania do wyższej temperatury niż glikol propylenowy. Temperatura podgrzania glicerolu nie powinna jednak przekraczać $100^{\circ} \mathrm{C}$, aby zapobiec powstawaniu toksycznej akroleiny. Nie można jednak uzyskać szczegółowych informacji na temat faktycznej temperatury podgrzania roztworu i przewiduje się, że może być wyższa [1]. Badania przeprowadzone przez Jensen i wsp. wykazały, że z pozornie nieszkodliwych substancji, takich jak glikol propylenowy i glicerol, w wyniku spalania w obecności tlenu i przy zbyt wysokiej temperaturze może powstać formaldehyd - substancja silnie drażniąca i toksyczna [9, 15, 18]. Stężenie formaldehydu może nawet przewyższać zawartość nikotyny. Formaldehyd przy regularnym wdychaniu zwiększa ryzyko powstania nowotworu nawet 15-krotnie, znacznie bardziej niż dym tytoniowy [18]. Pozostałe składniki to aromaty nadające odpowiedni smak, nikotyna i woda. Prawdopodobnie największe zagrożenie dla użytkowników e-papierosów stanowią substancje smakowe. Wprawdzie większość z nich została dopuszczona do wykorzystania w przemyśle spożywczym i kosmetycznym, ale nie przeprowadzono badań sprawdzających krótko- i długoterminowe skutki ich inhalacji [1, 9, 19-21]. Badania przeprowadzone przez Kucharską i wsp. wykazały rozbieżności pomiędzy składem roztworu inhalacyjnego deklarowanym przez producentów a składem faktycznym [22]. Najwięcej kontrowersji wywołuje diacetyl - substancja smakowa wykorzystywana do stworzenia smaku karmelowego. Jest to związek chemiczny, który można bezpiecznie spożywać, ale podczas inhalacji prowadzi do obturacji oskrzeli [9]. W aerozolu stwierdzono także obecność metali, takich jak nikiel, aluminium, kadm oraz krzem. Dokładny skład roztworów inhalacyjnych jest nieznany, a informacje udostępniane przez producentów niekompletne [23-26].

\section{Cytotoksyczne działanie aerozolu e-papierosów}

Aerozol powstały podczas palenia e-papierosów może powodować powstawanie wielu niekorzystnych skutków ubocznych, manifestujących się w jamie ustnej. Należy do nich obumieranie komórek nabłonka jamy ustnej oraz indukowanie odpowiedzi zapalnej. Szkodliwy wpływ nikotyny na tkanki przyzębia jest dobrze poznany, ale w przypadku e-papierosów większość wyszczególnionych skutków powstaje niezależnie od obecności nikotyny $w$ roztworze inhalacyjnym. Prawdopodobnie wskazuje to na szkodliwe działanie formaldehydu oraz zastosowanych substancji smakowych [9, 12, $13,18,27]$.
Nabłonek jamy ustnej jest szczelną, ale delikatną barierą, zapewniającą integralność ustroju oraz chroniącą organizm przed wnikaniem patogenów. Jeżeli bariera ta zostanie przerwana, zwiększa to ryzyko rozwoju infekcji. W badaniach in vitro zaobserwowano, że ekspozycja komórek nabłonka jamy ustnej na działanie aerozolu e-papierosów prowadzi do ich śmierci. Według badań przeprowadzonych na Uniwersytecie w Quebèc 24-godzinne narażenie na składniki roztworu inhalacyjnego powoduje obniżenie przeżywalności komórek keratynocytów o $18 \%$ w stosunku do komórek kontrolnych i wzrasta przy wydłużaniu czasu ekspozycji [28]. Podobną cytotoksyczność wykazały badania prowadzone przez Yu i wsp., wskazując dodatkowo nasilone obumieranie komórek niezależnie od obecności nikotyny w aerozolu. Keratynocyty poddane ekspozycji na aerozol e-papierosów niezawierający nikotyny wykazały 53-68\% zwiększenie występowania nekrozy komórek oraz nawet dwukrotne apoptozy w porównaniu z komórkami kontrolnymi. Wskazuje to na indukowanie śmierci komórek przez aerozol e-papierosów zarówno na drodze nekrozy, jak i apoptozy [27]. Śmierć komórek keratynocytów w wyniku działania aerozolu e-papierosów potwierdzają również Rouabhia i wsp. w eksperymencie przeprowadzonym in vitro na ludzkich komórkach nabłonka dziąsłowego [29]. E-papierosy, według badań wykonanych w Anglii przez Holliday i wsp, działają cytotoksycznie na keratynocyty jamy ustnej w wyniku indukowania stresu oksydacyjnego [30]. Stres oksydacyjny jest zaburzeniem równowagi pomiędzy generowaniem reaktywnych form tlenu a zdolnością do ich szybkiej detoksykacji. Przyczyną jest obniżenie stężenia glutationu w komórkach, prawdopodobnie spowodowane zawartością metali ciężkich w aerozolu [13, 31].

Aerozol powstały podczas palenia papierosów elektronicznych działa szkodliwie nie tylko na tkankę nabłonkową, ale również na fibroblasty struktur przyzębia. Badania przeprowadzone w Centrum Medycznym w Rochester przez Sundar i wsp. wykazały, że roztwory inhalacyjne zawierające substancje aromatyzujące indukowały powstawanie stresu oksydacyjnego oraz zwiększenie uwalniania cytokin prozapalnych. Zwiększeniu uległa ilość prostaglandyny $E_{2}$, cyklooksygenazy-2 oraz interleukiny-8 [12]. Rozwój stanu zapalnego, ze współistniejącym uszkodzeniem DNA, może prowadzić do obniżenia potencjału regeneracyjnego komórek [12, 32, 33]. Wzrost wydzielania cytokin prozapalnych został również potwierdzony przez Meo i wsp. [34] oraz Carvellati i wsp. [35]. Na podstawie przeprowadzonych badań można przypuszczać, że regularne palenie e-papierosów powoduje stale 
utrzymujący się stan zapalny, co predysponuje do rozwoju między innymi chorób przyzębia. W wyniku działania substancji aromatycznych z roztworów inhalacyjnych zaobserwowano również zachodzenie kolejnej reakcji chemicznej - karbonylacji białkowej, która prowadzi do zwiększenia liczby produkowanych przeciwciał i w konsekwencji utraty kości w przebiegu choroby przyzębia [36-38].

Według badań przeprowadzonych przez Wu i wsp. roztwory inhalacyjne e-papierosów, zarówno zawierające nikotynę, jak i jej pozbawione, mają negatywny wpływ na komórki nabłonkowe dróg oddechowych, promując odpowiedzi zapalne. Powodują znaczący wzrost zawartości IL-6 i IL-8 niezależnie od obecności nikotyny w roztworze. Wu i wsp. sugerują, że e-papierosy, nasilając stan zapalny, sprzyjają infekcjom górnych dróg oddechowych w podobnym stopniu, jak dym tytoniowy [39].

Badania przeprowadzone przez Lerner i wsp. udowodniły, że olejki elektronicznych papierosów, działające bezpośrednio na komórki nabłonkowe płuc, zmieniają ich morfologię. Nasilenie odpowiedzi zależy od zawartości nikotyny i zastosowanego smaku olejku. Po zadziałaniu roztworu inhalacyjnego na komórki ich filopodia ulegają skróceniu, podobnie jak filopodia fibroblastów więzadeł przyzębnych po zadziałaniu nikotyny. Zaobserwowano również zwiększenie liczby wakuoli w komórkach, co prawdopodobnie jest spowodowane zwiększeniem stresu oksydacyjnego $\mathrm{w}$ wyniku działania substancji smakowych. Autorzy zwrócili również uwagę na fakt, iż glikol propylenowy może zwiększać transport substancji smakowych i innych potencjalnie toksycznych związków do komórek nabłonkowych, zwłaszcza, że jest stosowany w systemach transdermalnych dla zwiększenia penetracji leków [40].

Sussan i wsp. w badaniach przeprowadzonych za myszach zaobserwowali, że ekspozycja na e-papierosy powoduje infiltrację makrofagów do dróg oddechowych. Jest to zjawisko podobne do odpowiedzi zapalnej powstałej po ekspozycji na dym tytoniowy [41].

Składniki zawarte w dymie pochodzącym z e-papierosów mają niekorzystny wpływ na zachowanie prawidłowej struktury DNA komórek nabłonka jamy ustnej. W badaniach przeprowadzonych przez Sundar i wsp. oraz Yu i wsp. w warunkach in vitro zaobserwowano pękanie podwójnej helisy DNA $[12,27]$. Najprawdopodobniej odpowiedzialny jest za to formaldehyd powstały po podgrzaniu roztworu do zbyt wysokiej temperatury. Dokładny mechanizm reakcji nie został jeszcze poznany, ale przypuszcza się, że w proces zaangażowane są reaktywne formy tlenu, powodujące destrukcję DNA [42, 43]. Powtarzalne działanie czynników indukujących uszkodzenie materiału genetycznego, w połączeniu z zaburzeniem działania komórkowych systemów naprawczych, prowadzi do powstania mutacji, co może skutkować rozwojem nowotworu. Wielu badaczy obserwowało, że uszkodzenia DNA występowały niezależnie od zawartości nikotyny, ale jej obecność nasilała obserwowane zjawiska [12, 27, 42, 44].

\section{Podsumowanie}

Wyniki badań prowadzonych w wielu ośrodkach naukowych w Europie i Stanach Zjednoczonych wskazują na niekorzystne zjawiska, które mogą zachodzić w nabłonku jamy ustnej podczas palenia papierosów elektronicznych. Krótkoterminowe skutki działania e-papierosów są niepokojące, a długotrwałe efekty ich użytkowania nie zostały jeszcze poznane. Stanowi to podstawę do prowadzenia dalszych, bardziej szczegółowych badań i weryfikacji powszechnie panującej opinii o niewielkiej szkodliwości palenia e-papierosów.

\section{Oświadczenia}

Oświadczenie dotyczące konfliktu interesów

Autorzy deklarują brak konfliktu interesów w autorstwie oraz publikacji pracy.

\section{Źródła finansowania}

Autorzy deklarują brak źródeł finansowania.

\section{Piśmiennictwo}

[1] Bertholon JF, Becquemin MH, Annesi-Maesano I, Dautzenberg B. Electronic Cigarettes: A Short Review. Respiration. 2013;86:433-438.

[2] Ayers JW, Ribisl KM, Brownstein JS, Tracking the rise in popularity of electronic nicotine delivery systems (electronic cigarettes) using search query surveillance. Am J Prev Med. 2011;40: 448-453.

[3] Goniewicz ML, Gawron M, Nadolska J, Balwicki Ł, Sobczak A, Rise in Electronic Cigarette Use Among Adolescents in Poland. J Adelesc Health. 2014;55:713-715.

[4] Etter JF, Bullen C, Electronic Cigarette: users profile, utilization, satisfaction and perceived efficiancy. Addiction. 2011;106:2017-2028.

[5] Pisinger C, Dossing M, A systematic review of health effects of electronic cigarettes. Prev Med 2014;69:248-260.

[6] Manzoli L, La Vecchia C, Flacco ME, Capasso L, Simonetti V, Boccia S, et al. Multicentric cohort study on the long-term efficacy and safety of electronic cigarettes: study design and methodology. BMC public health. 2013;13:883.

[7] Manzoli L, Flacco ME, Fiore $\mathrm{M}$ et al. Electronic cigarettes efficacy and safety at 12 months: cohort study. PLoS ONE 2015;10(6):e0129443.

[8] Manzoli L, Flacco ME, Ferrante $M$ the ISLESE Working Group, et al., Cohort study of electronic cigarette use: effectiveness and safety at 24 months, Tobacco Control 2017;26:284-292.

[9] Holliday R, Stubbs C. A Dental Perspective On Electronic Cigarettes: The Good, The Bad and The Ugly. Oral Health. 2015(6)

[10] Pisinger C, Dossing M, A systematic review of health effects of electronic cigarettes. Prev Med 2014;69:248-60.

[11] Burstyn I. Peering through the mist: systematic review of what the chemistry of contaminants in electronic cigaret- 
tes tells us about health risks. BMC Public Health. 2014. Doi: 10.1186/1471-2458-14-18.

[12] Sundar IK, Javed F, Romanos GE, Rahman I. E-cigarettes and flavorings induce inflammatory and pro-senescence responses in oral epithelial cells and periodontal fibroblasts. Oncotarget. 2016;7(47): 77196-77204.

[13] Ji EH, Sun B, Zhao T, Shu S, Chang CH, Messadi D, Xia T, Zhu Y, Hu S. Characterization of Electronic Cigarette Aerosol and Its Induction of Oxidative Stress Response in Oral Keratinocytes. PLoS ONE 2016; 11(5)

[14] Callahan-Lyon P. Electronic cigarettes: human health effects. Tob Control. 2014;23:36-40.

[15] McKee M, Capewell S, Evidence about electronic cigarettes: a foundation built on rock or sand?, BMJ 2015;351:h4863.

[16] McNeill A, Brose LS, Calder R, Hitchman SC, Hajek P, McRobbie H. E-cigarettes: an evidence update. A report commissioned by Public Health England. 2015.

[17] Brown CJ, Cheng JM. Electronic cigarettes: product characterisation and design considerations. Tob Control. 2014 May;23 Suppl 2:4-10.

[18] Jensen RP, Luo W, Pankow JF, Strongin RM, Peyton DH. Hidden Formaldehyde in E-Cigarette Aerosols. N Engl J Med. 2015; 372:392-394.

[19] Khlystov A, Samburova. Flavoring Compounds Dominate Toxic Aldehyde Production during E-Cigarette Vaping. Environmental Science and Technology 11/2016.

[20] Ingebrethsen BJ, Cole SK, Alderman SL. Electronic cigarette aerosol particle size distribution measurements. Inhalation toxicology. 2012;24(14):976-84.

[21] Leigh NJ, et al. Flavourings significantly affect inhalation toxicity of aerosol generated from electronic nicotine delivery systems (ENDS), Tob Control. 2016;25:ii81-ii87. Doi: 10.1136/tobaccocontrol-2016-053205.

[22] Kucharska M, Wesolowski W, Czerczak S, Socko R. Testing of the composition of e-cigarette liquids - Manufacturer-declared vs. true contents in a selected series of products. Med Pr. 2016;67(2):239-253.

[23] Williams M, Villarreal A, Bozhilov K, Lin S, Talbot P. Metal and silicate particles including nanoparticles are present in electronic cigarette cartomizer fluid and aerosol. PLoS One. 2013;8(3)

[24] Goniewicz ML, Knysak J, Gawron M, Kosmider L, Sobczak A, Kurek J, Prokopowicz A, Jablonska-Czapla M, RosikDulewska C, Havel C, Jacob P 3rd, Benowitz N. Levels of selected carcinogens and toxicants in vapour from electronic cigarettes. Tob Control. 2014 Mar;23(2):133-139.

[25] Williams M, Villarreal A, Bozhilov K, Lin S, Talbot P. Metal and silicate particles including nanoparticles are present in electronic cigarette cartomizer fluid and aerosol. PLoS ONE 2013. Doi: 10.1371/journal.pone.0057987.

[26] Cheng T. Chemical evaluation of electronic cigarettes. Tob Control. 2014;23:11-17.

[27] Yu V, Rahimy M, Korrapati A. Electronic cigarettes induce DNA stand breaks and cell death independently of nicotine in cell lines. Oral Oncology. 2016;52:58-65.

[28] Semlali A, Chakir J, Goulet JP, Chmielewski W, Rouabhia M. Whole cigarette smoke promotes human gingival epithelial cell apoptosis and inhibits cell repair processes. Journal of Periodontal Research. 2011, Doi 10.1111/j.1600 $-0765.2011 .01370 x$

[29] Rouabhia M, Park HJ, Semlali A, Zakrzewski A, Chmielewski W, Chakir J, E-Cigarette Vapor Induces an Apoptotic Response in Human Gingival Epithelial Cells Through the Caspase-3 Pathway, J. Cell. Physiol. 232: 1539-1547, 2017.

[30] Holliday R, Kist R, Bauld L. E-cigarette vapour is not inert and exposure can lead to cell damage. Evidence-Based Dentistry 2016;17:2-3.

[31] Lerner CA, Sundar IK, Yao H, Gerloff J, Ossip DJ, McIntosh $\mathrm{S}$, et al. Vapors Produced by Electronic Cigarettes and
E-Juices with Flavorings Induce Toxicity, Oxidative Stress, and Inflammatory Response in Lung Epithelial Cells and in Mouse Lung. PLoS ONE. 2015;10(2):e0116732.

[32] Tinti F, Soory M. Mechanisms for redox actions of nicotine and glutathione in cell culture, relevant to periodontitis. Sci Rep. 2012;2:566.

[33] Tinti F, Soory M. Oxidative actions of hydrogen peroxide in human gingival and oral perosteal fibroblasts: responses to glutathione and nicotine, relevant to healing in a redox environment. Redox Biol. 2013;2:36-43.

[34] Meo SA, Al Asiri SA, Effects of electronic cigarette smoking on human health, Eur Rev Med Pharmacol Sci. 2014;18(21):3315-9.

[35] Cervellati F, Muresan X, Sticozzi C, Gambari R, Montagner G, Forman H, Torricelli C, Maioli E, Valacchi G, Comparative effects between electronic and cigarette smoke in human keratinocytes and epithelial lung cells, Toxicol In Vitro. 2014 Aug; 28(5): 999-1005.

[36] Sancilio S, Gallorini M, Cataldi A. Cytotoxicity and apoptosis induction by e-cigarette fluids in human gingival fibroblasts. Clin Oral Invest. 2016;20: 477-483.

[37] Willershausen I, Wolf T, Weyer V, Sader R, Ghanaati S, Willershausen B. Influence of E-smoking on human periodontal ligemant fibroblasts. Head \& Face Medicine. 2014 Doi: 10.1186/1746-160X-10-39.

[38] Inkielewicz-Stępniak I, Kusiak A, Wojtaszek-Słomińska A, Niska K, Szkarłat B. The impact od electronic cigarette liquids on human gingival cell viability - a preliminary in vitro study. Dental Forum. 2016;1:17-20.

[39] Wu Q, Jiang D, Minor M, Chu HW. Electronic Cigarette Liquid Increases Inflammation and Virus Infection in Primary Human Airway Epithelial Cells, Plos One. 2014, Doi. org/10.1371/journal.pone.0108342.

[40] Lerner CA, Sundar IK, Yao H i wsp. Vapors Produced by Electronic Cigarettes and E-Juices with Flavorings Induce Toxicity, Oxidative Stress, and Inflammatory Response in Lung Epithelial Cells and in Mouse Lung; Plos One. 2015, Doi.org/10.1371/journal.pone.0116732.

[41] Sussan TE, Gajghate S, Thimmulappa RK; Exposure to Electronic Cigarettes Impairs Pulmonary Anti-Bacterial and Anti-Viral Defenses in a Mouse Model; Plos One. 2015, Doi.org/10.1371/journal.pone.0116861.

[42] Cooke MS, et al. Oxidative DNA damage: mechanisms, mutation, and disease. Faseb j. 2003;17(10):1195-214.

[43] De Bont R, van Larebeke N. Endogenous DNA damage in humans: a review of quantitative data. Mutagenesis. 2004;19(3):169-85.

[44] Squier CA, Mantz MJ, Wertz PW. Effect of menthol on the penetration of tobacco carcinogens and nicotine across porcine oral mucosa ex vivo. Nicotine Tob Res. 2010;12(7): 763-767.

Zaakceptowano do edycji: 2017-10-12 Zaakceptowano do publikacji: 2017-11-22
Adres do korespondencji:
Aida Kusiak
Katedra i Zakład Periodontologii i Chorób Błony Śluzowej Jamy Ustnej Uniwersytet Medyczny w Gdańsku ul. Orzeszkowej 18, 80-204 Gdańsk tel./fax: 583491667 e-mail: akusiak@gumed.edu.pl 